\title{
ANALISIS PERBANDINGAN KINERJA KEUANGAN PERBANKAN SYARIAH (Studi: BNI Syariah dan BRI Syariah)
}

\section{COMPARATIVE ANALYSIS OF ISLAMIC BANKING FINANCIAL PERFORMANCE (Study BNI SHARIA AND BRI SHARIA)}

\author{
Dian Asri Fitriah'1a; Afiati Kurniasih²b \\ 1aJurusan Ekonomi Islam Fakultas Perbankan Syariah Universitas Djuanda, Jl. Tol Ciawi \\ No. 1, Kotak Pos 35 Bogor 16720 \\ 2bJurusan Perbankan Syariah Fakultas Ekonomi Islam Universitas Djuanda, Jl. Tol Ciawi \\ No. 1, Kotak Pos 35 Bogor 16720
}

(Diterima oleh Dewan Redaksi 10-06-2016)

(Dipublikasikan oleh Dewan Redaksi 01-12-2016)

\begin{abstract}
Financial performance BNI Sharia BRI Sharia and get a big profit other than Islamic banking. This is evidenced by the amount of profit earned by BNI Syariah amounted to 265.6 billion rupiah and BRI Syariah makes a profit of 12 billion rupiah. Therefore, this study was made untu compare the financial performance between BNI Syariah BRI Syariah and to specify the variables that determine financial performance such as CAR, NPF, FDR, ROA, ROA, and ROE. Data analysis tools in this study used quantitative descriptive analysis which takes its data from the Annual Report Sharia BRI and BNI Sharia from 2011 to 2015. The data management by using T-test and regression, with the help of SPSS application program. The conclusion of this study is the existence of some differences in the magnitude of the ratios of BNI Sharia and BRI Sharia. Thus the BNI Sharia has better performance than the BRI Sharia in 2011 to 2015.
\end{abstract}

Keyword: Financial Performance, BNI Sharia, BRI Sharia

\begin{abstract}
ABSTRAK
Kinerja keuangan BNI Syariah dan BRI Syariah mendapatkan profit yang besar dibandingkan perbankan syariah yang lain. Ini dibuktikan dengan jumlah profit yang didapatkan oleh BNI Syariah sebesar 265,6 miliar rupiah dan BRI Syariah yang mendapatkan profit sebesar 12 miliar rupiah. Oleh karena itu penelitian ini dibuat untu mengetahui perbandingan kinerja keuangan diantara BNI Syariah dan BRI Syariah untuk menentukan variabel-variabel yang menentukan kinerja keuangan seperti CAR, NPF, FDR, BOPO, ROA, dan ROE. Alat analisis data dalam penelitian ini menggunakan analisis deskriptif kuantitatif yang mengambil datanya dari Annual Report BRI Syariah dan BNI Syariah dari tahun 2011 sampai dengan tahun 2015. Pengelolaan data dengan menggunakan T-test dan Regresi, dengan bantuan program aplikasi SPSS. Kesimpulan dari penelitian ini adalah adanya beberapa perbedaan besarnya rasio-rasio dari BNI Syariah dan BRI Syariah. Dengan demikian BNI Syariah memiliki kinerja lebih baik daripada BRI Syariah pada tahun 2011 sampai 2015.
\end{abstract}

Kata Kunci: Kinerja Keuangan, BNI Syariah, BRI Syariah 
Dian Asri Fitriah. 2016. Analisis Perbandingan Kinerja Keuangan Perbankan Syariah (Studi: BNI Syariah dan BRI Syariah). (3): 256- 264

\section{PENDAHULUAN}

Pertumbuhan ekonomi Islam telah berkembang pesat beberapa tahun terakhir. Khususnya pertumbuhan jumlah lembaga keuangan yang berbasis Islam, baik bank maupun non-bank seperti asuransi syariah, pasar modal syariah, pegadaiaan syariah, koperasi syariah, reksadana syariah, obligasi syariah serta leasing syariah.

Dari banyaknya lembaga keuangan, baik bank maupun non bank, perbankan adalah salah satu lembaga keuangan yang paling berperan dalam perekonomian suatu Negara dan tidak dapat dipungkuri bahwa ekonomi disuatu negara sangat mempengaruhi kinerja perbankan. Salah satunya krisis finansial juga pada era 90an yang berdampak pada kinerja keuangan perbankan di Indonesia. Pada era tersebut perbankan mengalami kinerja keuangan yang sangat buruk, sehingga beberapa bank milik pemerintah terpaksa di akuisisi, dan di marger, serta ada pula yang dijual pada pihak swasta, krisis perbankan berkaitan erat dengan sistem ekonomi makro, kebijakan moneter pemerintah, kebijakan fiskal, sistem pemerintahan, aspek hukum, politik, sosial, dan sebagainya. Adapun kinerja perbankan syariah yang pada saat itu hanya Bank Muamalat, juga terkena dampak krisis. Hal ini terlihat dari tingginya rasio pembiayaan macet (NPF) yang mencapai lebih dari 60\%.

Penilaian kesehatan suatu bank bertujuan untuk mengetahui kondisi perbankan apakah berada dalam posisi sehat, cukup sehat, kurang sehat atau tidak sehat. Selain itu, penilaian kesehatan bank juga akan berpengaruh terhadap loyalitas nasabah pada bank yang bersangkutan. Untuk mengetahui kondisi kesehatan bank tersebut dapat dibuktikan melalui berbagai alat ukur. Salah satu alat untuk mengukur tingkat kesehatan bank adalah dengan menggunakan analisis CAMEL.

Berdasarkan UU Republik Indonesia No. 21 tahun 2008 tentang Perbankan Syariah pasal 51, pembinaan dan Pengawasan bank dilakukan oleh Otoritas Jasa Keuangan. UU tersebut lebih lanjut menetapkan bahwa, bank syariah wajib memelihara tingkat kesehatan yang meliputi sekurang-kurangnya mengenai kecukupan modal, likuiditas, rentabilitas, solvabilitas, kualitas manajemen Islami, dan hal-hal lainnya yang memiliki kaitan dengan usaha Bank Syariah.

\section{MATERI DAN METODE}

Kinerja religius islami adalah suatu pencapaian yang diperoleh sesorang atau organisasi dalam bekerja atau berusaha yang mengikuti kaidah-kaidah agama atau prinsip-prinsip ekonomi Islam. Terdapat beberapa dimensi kinerja Islami, yaitu:

1. Amanah dalam bekerja yang, seperti : professional, ibadah dan amal perbuatan,

2. Mendalami agama dan profesi, seperti : memahami nilai agama, dan tekun bekerja

Ada 4 (empat) metode yang digunakan dalam mengukur kinerja keuangan perusahaan selama ini, yaitu:

1. Metode Rasio Keuangan. Dalam metode ini pengukuran kinerja perusahaan lebih menekankan pada operasi keuangan yaitu: Likuidity Ratio, Leverage Ratio, Probabilitas Ratio, dan Activity Ratio.

2. Metode Economic Value Added (EVA). Metode ini memfokuskan pada penerapan nilai proses kinerja dalam periode 1 (satu) tahun. Dengan kata lain EVA merupakan pengukuran pendapatan sisa (residul income) yang 
mengurangi biaya modal terhadap laba operasi.

3. Metode Balance Scorecard (BSC). Pengukuran kinerja perusahaan menggunakan metode ini dilakukan dengan cara menyeimbangkan faktorfaktor keuangan dan nonkeuangan dari suatu perusahaan. Mempertimbangkan 4 aspek atau perspektif yaitu: prospektif keuangan, pelanggan, proses bisnis internal dan proses belajar dan berkembang.

4. Metode Radar, merupakan metode yang digunakan untuk melihat kinerja perusahaan yang menjadi penyempurna dari metode-metode sebelumnya. Rasio Radar mengelompokan rasionya menjadi 5 (lima) kelompok besar yaitu Rasio Profitabilias, Produktifitas, Utilitas Aktiva, Stabilitas, dan Rasio Pertumbuhan.

Adapun manfaat penilaian kerja sebagai berikut:

a. Untuk mengukur prestasi yang dicapai oleh suatu organisasi dalam periode tertentu yang mencerminkan tingkat keberhasilan suatu perusahaan.

b. Pengukuran kinerja dapat digunakan untuk menilai kontribusi suatu bagian dalam pencapaian tujuan perusahaan secara keseluruhan.

c. Dapat digunakan sebagai dasar strategi perusahaan untuk masa yang akan datang.

d. Sebagai bahan pertimbangan keputusan oleh para pemegang kepentigan pada sebuah perusahaan.

e. Sebagai dasar penarikan minat para investor dalam penanaman modal di pasar modal agar perusahaan dapat meningkatkan efisiensi dan produktivitas perusahaan

Kesehatan suatu bank merupakan kepetingan suatu pihak, yaitu: pemilik, pengelola bank dan masyarakat pengguna jasa bank. Tingkat kesehatan bank merupakan hasil penelitian kualitatif atas berbagai aspek yang berpengaruh terhadap kondisi dan atau kinerja suatu bank melalui penilaian faktor permodalan, kualitas aset, manajemen, rentabilitas, likuiditas.

\section{Skema Kerangka Pemikiran}

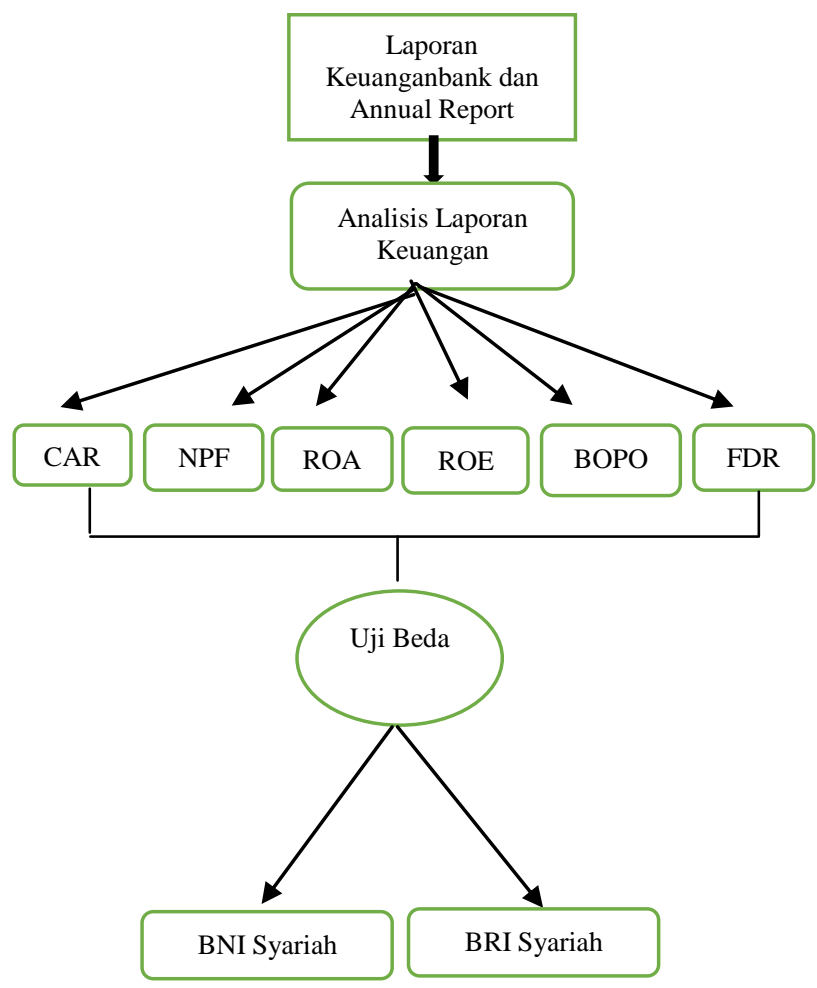

Gambar 1. Kerangka Pemikiran Sumber: Penulis, 2016

\section{Jenis dan Objek Penelitian}

Penelitian yang dilakukan menggunakan penelitian deskriptif kuantitatif, merupakan penelitian yang memberikan penjelasan atau gambaran secara terperinci terhadap suatu keadaan tanpa ada perlakuan terhadap objek yang diteliti.

Populasi dalam penelitian ini adalah BNI Syariah dan BRI Syariah. Sedangkan sampelnya adalah Laporan keuangan kedua bank tersebut dari tahun 2011 sampai pada tahun 2015. Dalam penelitian ini, teknik sampling yang digunakan adalah purposive sampling.

Objek penelitian adalah CAR, NPF, ROA, ROE, BOPO dan FDR pada BNI Syariah dan BRI Syariah tahun 2011-2015, 
dengan focus penelitian yaitu tentang analisis perbandingan kinerja perbankan syariah.

Data sekunder merupakan sumber utama dalam penelitian ini dimana datanya adalah Laporan keuangan dan Annual Report BNISyariah dan BRI Syariah dari tahun 2011-2015.

Teknik analisis yang digunakan penulis gunakan adalah T-test dan Regresi. Penelitian T-test adalah penelitian yang dipakai untukmembandingkan kedua objek penelitian. Sedangkan, Regresi adalah penelitian yang membuktikan seberapa besar pengaruh variabel-variabel tersebut terhadap kinerja perbankan syariah.

\section{HASIL DAN PEMBAHASAN}

\section{Gambaran Umum BNI Syariah}

Permintaan akan berdirinya perbankan yang berbasis syariah mulai bermunculan dari masyarakat. Banyaknya permintaan tersebut akhirnya menarik manajemen BNI untuk membuka layanan perbankan yang berbasis syariah, sehingga BNI menyediakan konsep dual banking system dan resmi berdiri sejak 29 April tahun 2000.

Dari awal operasinya layanan bank berbasis syariah, BNI Syariah menunjukkan pertumbuhan yang signifikan dengan dilihat dari jumlah cabang BNI Syariah pada juni 2014 mencapai 65 Kantor Cabang, 161 Kantor Cabang Pembantu, 17 Kantor Kas, 22 Mobil Layanan Gerak dan 20 Payment Point.

Kinerja keuangan BNI Syariah pada tahun 2013-2015 mengalami peningkatan yang cukup signifikan dari jumlah asset (Total Assets), Pembiayaan (Financing), dan Dana Pihak Ketiga (Third Party Fund). Hal ini membuktikan bahwa BNI Syariah mampu mengelola seluruh kinerjanya dengan sangat baik hingga dapat meningkatkan pendapatan dan juga kepercayaan masyarakat untuk menaruh dananya pada BNI Syariah. BNI Syariah mengalami peningakatan asetyang cukup signifikan setiap tahunnya hingga lebih dari Rp. 4.783.608 juta.

\section{Gambaran Umum BRI Syariah}

Awal mulanya BRI Syariah merupakan bank yang berada di bawah PT. Bank Rakyat Indonesia yang melakukan akuisisi terhadap Bank Jasa Arta pada tanggal 19 Desember 2007 dan setelah mendapatkan izin dari Bank Indonesia pada 16 oktober 2008 melalui suratnya No.10/67/KEP.GBI/DpG/2008, maka pada tanggal 17 Desember 2008 PT. Bank Rakyat Indonesia Syariah (BRI Syariah) secara resmi beroperasi. Setelah keluarnya surat tersebut, BRI Syariah mulai menjalankan kegiatan operasional perbankan berdasarkan prinsip syariah.

Aktivitas BRI Syariah semakin kokoh setelah tanggal 19 Desember 2008 dengan penandatanganan akta pemisahan Unit Usaha Syariah BRI, untuk berdiri sendiri menjadi BRI Syariah sebagai bank umum (proses spin off) yang berlaku efektif pada 1 Januari 2009.

Kinerja keuangan BRI Syariah juga mengalami peningkatan disetiap tahunnya dengan melihat Jumlah Aktiva (Total Assets), Aktiva produktif (Earnings Assets), pembiayaan (Financing), Dana Pihak Ketiga (Third Party Fund), Ekuitas Bersih (Equity Net), dan Laba Rugi tahun berjalan sebelum Pajak (Profit Loss Current Year Before Tax). Bahkan Kenaikan jumlah saham BRI Syariah mencapai Rp. 3.889.214 juta 3 tahun terakhir.

Dalam penelitian ini, untuk menguji hipotesis peneliti menggunakan T-test dan Regresi linear berganda yang dimaksud untuk mengetahui apakah ada perbedaan kinerja keuangan antara BRI Syariah dan BNI Syariah dan manakah bank yang memiliki kinerja keuangan yang lebih baik, dan untuk mengetahui pengaruh variabel bebas (Independent) $\mathrm{X}$ yang terdiri dari 6 variabel, yaitu: CAR, NPF, 
NIM, BOPO dan FDR, terhadap Variabel terikat (Dependent), yaitu: ROA.

Perhitungan menggunakan metode $\mathrm{T}$ test yang dihitung menggunakan program aplikasi SPSS. Dari hasil Tabel Independent Samples T-test menyajikan enam variabel, terdiri dari variabel CAR (X1), NPF (X2), ROA (X3), ROE (X4), BOPO (X5), dan FDR (X6).

a. Bila kedua varians sama, maka sebaiknya asumsi yang dapat dioperasikan menggunakan Equal variance assumed (diasumsi kedua varian sama). $\mathrm{T}$ hitung untuk CAR dengan Equal variance assumed adalah 2.856, dengan probabilitas 0.021 oleh karena $0.021<0.05$, maka $\mathrm{H} 0$ ditolak dan $\mathrm{H} 1$ diterima atau dapat dikatakan bahwa jika dilihat dari rasio CAR maka kinerja BNI Syariah dan kinerja BRI Syariah terdapat perbedaan.

b. Bila kedua varians sama, maka asumsi yang dapat dilakukan sebaiknya menggunakan Equal variance assumed (diasumsi kedua varian sama). $\mathrm{T}$ hitung untuk NPF dengan Equal variance assumed adalah -3.042, dengan probabilitas 0.016 oleh karena $0.016<0.05$, maka H0 ditolak dan H1 diterima atau dapat dikatakan bahwa jika dilihat dari rasio NPF maka kinerja BNI Syariah dan kinerja BRI Syariah terdapat perbedaan.

c. Bila kedua varians berbeda, maka untuk membandingkan kedua populasi dengan T-Test sebaiknya menggunakan dasar Equal variance not assumed (diasumsi kedua varian tidak sama). Terlihat bahwa t hitung untuk ROA dengan Equal variance not assumed adalah 2.938, dengan probabilitas 0.040 oleh karena 0.040 < 0.05, maka H0 ditolak dan H1 diterima atau dapat dikatakan bahwa jika dilihat dari rasio ROA maka kinerja BNI Syariah dan kinerja BRI Syariah terdapat perbedaan. d. Bila kedua varians berbeda, maka untuk membandingkan kedua populasi dengan T-Test sebaiknya menggunakan dasar Equal variance not assumed (diasumsi kedua varian tidak sama). Terlihat bahwa t hitung untuk ROE dengan Equal variance not assumed adalah 1.877, dengan probabilitas 0.108 oleh karena 0.108 $>0.05$, maka H0 diterima dan $\mathrm{H} 1$ ditolak atau dapat dikatakan bahwa jika dilihat dari rasio ROE maka kinerja BNI Syariah dan kinerja BRI Syariah tidak memiliki perbedaan.

e. Bila kedua varians sama, maka sebaiknya menggunakan Equal variance assumed (diasumsi kedua varian sama). T hitung untuk BOPO dengan Equal variance assumed adalah -3.933, dengan probabilitas 0.04 oleh karena $0.004<0.05$, maka $\mathrm{H} 0$ ditolak dan $\mathrm{H} 1$ diterima atau dapat dikatakan bahwa jika dilihat dari rasio BOPO maka kinerja BNI Syariah dan kinerja BRI Syariah terdapat perbedaan.

f. Bila kedua varians sama, maka sebaiknya menggunakan Equal variance assumed (diasumsi kedua varian sama). $\mathrm{T}$ hitung untuk FDR dengan Equal variance assumed adalah -1.152, dengan probabilitas 0.283 oleh karena $0.283>0.05$, maka $\mathrm{H} 0$ diterima dan $\mathrm{H} 1$ ditolak atau dapat dikatakan bahwa jika dilihat dari rasio FDR maka kinerja BNI Syariah dan kinerja BRI Syariah tidak ada perbedaan. Nilai eror NPF pada BNI Syariah dan BRI Syariah ini cukup besar yaitu 0.283 , hal ini dipengaruhi oleh jumlah pembiayaan yang diberikan oleh bank tidak menghasilkan keuntungan seluruhnya karena adanya nasabah pembiayaan yang mengalami gagal bayar.

Kinerja keuangan antara BNI Syariah dengan BRI Syariah dari tahun 2011 sampai dengan tahun 2015. Dari hasil penelitian ini dapat diketahui bahwa BNI 
Syariah memiliki kinerja keuangan lebih baik dibandingkan dengan BRI Syariah pada tahun 2011 sampai dengan BNI Syariah

\section{Analisis Regresi Berganda BNI Syariah}

Tabel 1. Regresi BNI Syariah

\begin{tabular}{|c|c|c|c|c|}
\hline \multirow{2}{*}{\multicolumn{2}{|c|}{ Model }} & \multicolumn{2}{|c|}{$\begin{array}{l}\text { Unstandardized } \\
\text { Coefficients }\end{array}$} & \multirow{2}{*}{$\begin{array}{c}\text { Standardized } \\
\text { Coefficients }\end{array}$} \\
\hline & & B & Std. Error & \\
\hline \multirow[t]{5}{*}{1} & $\begin{array}{l}\text { (Cons } \\
\text { tant) }\end{array}$ & $\begin{array}{r}60.76 \\
9\end{array}$ & .000 & \\
\hline & $\mathrm{x} 1$ & 2.505 & .000 & 43.138 \\
\hline & $\mathrm{x} 2$ & .477 & .000 & 39.852 \\
\hline & x3 & 1.748 & .000 & -20.609 \\
\hline & $\mathrm{x} 4$ & 2.031 & .000 & -16.934 \\
\hline
\end{tabular}

Sumber: Data Diolah 2016

$Y=60.77+2.5+0.48+(-1.75)+(-2.03)$

a. Konstanta sebesar $60.77 \%$, artinya jika CAR, NPF, BOPO dan FDR nilainya adalah 0 , maka ROA nilainya sebesar $60.77 \%$.

b. Koefisien regresi variabel CAR (X1) sebesar 2.50\%, artinya setiap peningkatan CAR sebesar 1, maka akan meningkatkan ROA sebesar $2.50 \%$. Sesuai pada jurnal yang berjudul faktor-faktor yang mempengaruhi kinerja keuangan pada bank di Indonesia bahwa kenaikan CAR berpengaruh positif terhadap ROA, maka kenaikan rasio CAR akan berdampak pada kenaikan ROA, karena Aset milik bank akan ditempatkan pada Aset-aset produktif yang akan menghasilkan keuntungan pada bank. Hal ini sejalan dengan hasil penelitian Margareth (2014).

c. Koefisien regresi variabel FDR (X2) sebesar $0.48 \%$, artinya setiap peningkatan FDR sebesar 1, maka akan meningkatkan ROA sebesar $0.48 \%$. FDR digunakan untuk menyalurkan pembiayaan kepada masyarakat naik maka akan menaikan return yang akan diterima oleh bank. Hal ini sejalan dengan hasil penelitian Yuliany (2014)

d. Koefisien regresi variabel BOPO (X3) sebesar $-1.748 \%$, artinya setiap peningkatan BOPO sebesar 1, maka akan menurunkan ROA sebesar 1.748\%. maka setiap kenaikan BOPO akan menurunkan keuntungan bank. Hal ini juga sejalan dengan hasil penelitian Alifah (2014).

e. Koefisien regresi variabel NPF (X4), sebesar $-2.03 \%$, artinya setiap peningkatan NPF sebesar 1, maka akan menurunkan ROA sebesar 2.03\%. karena semakin besar jumlah nasabah yang mengalami pembiayaan macet maka akan menurunkan return pada bank tersebut, hal ini sejalan dengan hasil penelitian Fahmy (2013).

\section{Analisis Regresi Berganda BRI Syariah}

Tabel 2. Regresi BRI Syariah

\begin{tabular}{|c|c|c|c|c|}
\hline \multirow{2}{*}{\multicolumn{2}{|c|}{ Model }} & \multicolumn{2}{|c|}{$\begin{array}{l}\text { Unstandardized } \\
\text { Coefficients }\end{array}$} & \multirow{2}{*}{$\begin{array}{c}\begin{array}{c}\text { Standardized } \\
\text { Coefficients }\end{array} \\
\text { Beta }\end{array}$} \\
\hline & & B & Std. Error & \\
\hline \multirow[t]{5}{*}{1} & $\begin{array}{l}\text { (Cons } \\
\text { tant) }\end{array}$ & 8.422 & .000 & 0.240 \\
\hline & $\mathrm{x} 1$ & 0.90 & .000 & 0.035 \\
\hline & $\mathrm{x} 2$ & 0.02 & .000 & 39.852 \\
\hline & x3 & 0.100 & .000 & -1.087 \\
\hline & $\mathrm{x} 4$ & $0.049^{-}$ & .000 & -0.89 \\
\hline
\end{tabular}

Sumber: Data Diolah 2016

$$
\begin{aligned}
& \mathrm{Y}=8.422+0.09+0.002+(-0.1)+(- \\
& 0.05)
\end{aligned}
$$

a. Konstanta sebesar 66.77, artinya jika CAR, FDR, BOPO, dan NPF pada ROA nilainya adalah 0 , maka ROA nilainya sebesar $8.42 \%$. 
b. Koefisien regresi variabel CAR (X1) sebesar $0.9 \%$, artinya setiap peningkatan CAR sebesar 1, maka akan meningkatkan ROA sebesar 0.9\%. CAR dapat menyalurkan Aseet bank kepada aset-aset produktif, bila CAR naik maka secara otomatis akan meningkatkan jumlah keuntungan untuk bank. Hal ini sejalan dengan penelitian yang dilakukan oleh Margaretha (2014).

c. Koefisien regresi variabel FDR (X2) sebesar $0.002 \%$, artinya setiap peningkatan FDR sebesar 1, maka akan meningkatkan FDR sebesar $0.002 \%$. semakin banyak pembiayaan yang diberikan oleh bank maka akan memberikan keuntungan pada bank (ROA naik).

d. Koefisien regresi variabel BOPO (X3) sebesar $-0.1 \%$, artinya setiap peningkatan BOPO sebesar 1, maka akan menurunkan ROA sebesar $-0.1 \%$. Semakin besar biaya operasional pada bank maka secara otomatis akan merurunkan return pada bank tersebut. Mengelola BOPO dengan baik maka akan menaikan keuntungan obank.

e. Koefisien regresi variabel NPF (X4) sebesar $-0.05 \%$, artinya setiap peningkatan NPF sebesar 1, maka akan menurunkan ROA sebesar $0.05 \%$. banyaknya jumlah kredit macet maka akan menurunkan keuntungan bank karena keuntungan bank yang seharusya diberikan oleh nasabah pembiayaan menjadi tidak. Hal ini sejalan dengan hasil penelitian Fahmy (2013).

\section{Analisis Perbandingan Regresi BNI Syariah dengan BRI Syariah}

Analisis perbandingan Regresi BNI Syariah dan BRI SYariah ini adalah bertujuan untuk mengetahui bank mana diantara kedua bank tersebut yang memiliki pengaruh variabel-variabel independent lebih besar.
Tabel 3. Perbandingan Regresi BNI Syariah dan BRI Syariah

\begin{tabular}{|l|l|l|}
\hline Variabel & BNI Syariah & BRI Syariah \\
\hline $\mathrm{Y}$ & 60.77 & 8.422 \\
\hline $\mathrm{X} 1$ & 2.5 & 0.09 \\
\hline $\mathrm{X} 2$ & 0.48 & 0.002 \\
\hline $\mathrm{X} 3$ & -1.75 & -0.1 \\
\hline $\mathrm{X} 4$ & -2.03 & -0.05 \\
\hline
\end{tabular}

Sumber: Data Diolah 2016

Keterangan:

Y: ROA BNI Syariah memiliki konstanta lebih besar dibandingkan dengan ROA BRI Syariah yaitu sebesar 60.77, sedangkan konstanta BRI Syariah hanya sebesar 8.422. hasil ini menunjukan bahwa BNI Syariah memiliki kinerja keuangan lebih baik dibandingkan kinerja keuangan BRI Syariah pada tahun 2011 sampai dengan tahun 2015.

X1: CAR BNI Syariah lebih berpengaruh terhadap return BNI Syariah dibandingkan dengan pengaruh CAR pada retun BRI Syariah. Hal ini menunjukan bahwa BNI Syariah memiliki kinerja lebih baik dibandingkan BRI Syariah pada tahun 2011 sampai dengan tahun 2015.

X2: FDR BNI Syariah berpengaruh lebih besar terhadap return BNI Syariah sebesar 0.48 dibandingkan dengan jumlah pengaruh FDR BRI Syariah terhadap return BRI Syariah yang hanya sebesar 0.09. dengan demikian hal ini menujukan bahwa BNI Syariah memiliki kinerja keuangan lebih baik dibandingkan dengan BRI Syariah periode 2011 sampai dengan 2015.

X3: BOPO BNI Syariah berpengaruh lebih besar terhadap return BNI Syariah sebesar -1.75 dibandingkan pengaruh BOPO BRI Syariah terhadap pendapatan BRI Syariah sebesar -0.1. Hal ini menunjukan bahwa BOPO pada BNI Syariah bisa di atur dengan baik karena mendapatkan keuntungan yang lebih besar dibandingkan BRI Syariah. Hal ini 
menunjukan bahwa jumlah biaya operasional BRI Syariah lebih kecil dibandingkan BNI Syariah.

X4: NPF BNI Syariah berpengaruh lebih besar terhadap return BNI Syariah sebesar -2.03 dibandingkan pengaruh NPF BRI Syariah terhadap return pada BRI Syariah. Hal ini menunjukan nahwa Jumlah NPF BNI Syariah yang cukup besar juga diimbangi dengan keuntungan yang besar pada CAR dan FDR pada BNI Syariah, sedangkan pengaruh NPF pada keuntungan BRI Syariah lebih kecil sejak periode 2011 sampai dengan tahun 2015.

\section{KESIMPULAN DAN IMPLIKASI}

Kinerja keuangan BNI Syariah dan BRI Syariah pada tahun 2011 sampai dengan tahun 2015 memiliki perbedaan dengan jumlah rasio CAR, NPF, ROA, ROE, BOPO dan FDR. Kinerja keuangan BNI SYariah lebih baik dibandingkan kinerja keuangan BRI Syariah pada tahun 2011 sampai dengan 2015.

Return On Assets (ROA) pada sebuah bank dipengaruhi oleh Capital Assets Ratio (CAR), Net Performing Financing (NPF), Beban Operasional terhadap Pendapatan Operasional (BOPO), Financing Deposite Ratio (FDR), dan Net Interest Margin (NIM). Hal ini dapat dilihat dari regresi BNI Syariah: $\mathrm{Y}=(-92.44)+0.12+0.85+$ $0.47+0.66$ dan Regresi BRI Syariah: Y= $10.39+0.086+(-0.003)+(-0.105)+(-$ $0.108)$. ini menyatakan bahwa pendapatan Bank BNI Syariah (ROA) sangat dipengaruhi oleh Rasio-rasio tersebut.

\section{DAFTAR PUSTAKA}

Abustan. 2009. Analisa Perbandingan Kinerja Keuangan Perbankan Syariah Dengan Perbankan Konvensional. Depok: Universitas Gunadarma

Angraini. 2012. Analisis Perbandingan Kinerja Keuangan Perbankan Syariah dengan Perbankan Kovensional
(Skripsi). Makassar: Universitas Hasanuddin

Ardiyana, Marissa. 2011. Analisis Perbandingan Kinerja Keuangan Bank Syariah dan Bank Konvensional, Sebelum, Selama, dan Sesudah Krisis Global Tahun 2008 (Skripsi). Semarang: Universitas Diponegoro

Darsono, Ashari. 2005. Pedoman Praktis Memahami Laporan Keuangan. Yogyakarta: Andi

Dendawijaya, Lukman. 2005. Manajemen Perbankan. Bogor: Glalia Indonesia

Dewi, Dhika Rahma. 2010. Faktor-Faktor Yang Mempengaruhi Profitabilitas Bank Syariah (Skripsi). Semarang: Universitas Diponegoro

Fahmi, Irham. 2012. Analisis Laporan Keuangan. Bandung: Alfabeta

Irawan, mul. 2014. Indikator Kinerja Islami dan Kinerja Konvensional Berdasarkan Teori dan Al-Qur'an dan Hadits. Surabaya: Universitas Airlangga

Jumiharni, Nila. 2013. Analisis Swot PT. Pertamina Persero. Lambung:Universitas Lambung Barat

Kadir. 2015. Statistika Terapan. Jakarta: RajaGrafindo

Kasmir. 2012. Manajemen Perbankan. Jakarta: Rajawali Pers

Kuncoro, Mudrajaddan Suhardjo. 2012. Manajemen Perbankan.

Yogyakarta:BPPE

Laporan Keuangan Tahunan BNI Syariah tahun 2011-2015

Laporan Keuangan Tahunan BRI Syariah tahun 2011-2015

Muhammad. 2014. Manajemen Dana Bank Syariah. Jakarta: Rajawali Pers

Munawir, S, 2013, Analisa Laporan Keuangan. Yogyakarta: Liberty

Murbarani, Desi Yulistiana. 2008. Analisis Perbandingan Kinerja Perbankan Syariah dan Perbankan Konvensioal dengan Metode CAMELS (Skripsi). Jember: Universitas Jember 
Nurastuti, Wiji. 2014. Teknologi Perbankan. Yogyakarta: Graha Ilmu

Pernyataan Standar Akuntansi Indonesia. 2000, 2004.

Purwanto, Tri Joko. 2011. Analisis Besarnya Pengaruh Pembiayaan, Financing To Deposit Ratio (FDR) dan Rasio Non Performing Financing (NPF) Terhadap Laba Bank Syariah (Skripsi). Bogor: Institut Pertanian Bogor

Ramlan, Hamidan, Mohd Sharizzat Adnan. (2015). The Profitability of Islamicand Conventional Bank: Case Study in Malaysia. Elsevier B.V. (http://creativecommons.org/licenses/b $y-n c-n d / 4.0 /)$.

Republik Indonesia. 2008. UndangUndang No. 21 pasal 51 tentang Perbankan Syariah

Sakinah, Fitria. 2013. Faktor-Faktor yang Mempengaruhi CAPITAL ADEQUACY RATIO (CAR) pada Bank Syariah di Indonesia periode maret 2009Desember 2011 (Skripsi). Jakarta: Universitas Islam Negeri Syarif Hidatullah

Siamat, Dahlan. 2005. Manajemen Lembaga Keuangan. Jakarta: Salemba

Sinungan, $\quad$ Muchdarsah. 2000. Produktivitas Apa dan Bagaimana. Jakarta: BumiAksara

Sugiyono. 2006. Teknik Penelitian. Bandung: Suharsimi Arikunto

Utami, Tusi. 2014. Pengaruh Kenaikan Tingkat Suku Bungan LPS Terhadap Dana Pihak Ketiga (Skripsi). Semarang: Universitas Semarang.

Wahyuni. 2012. Analisis Pengaruh Kinerja Keuangan (skripsi). Makassar: Universitas Hasanuddin 